\title{
YOU ARE HERE
}

\section{A GUIDED TOUR OF THE OSHKOSH CORRECTIONAL INSTITUTION PRISON LIBRARY \\ by \\ Randy Purifoy}

The Oshkosh Correctional Institution Library serves an inmate population of 1800 plus. Scheduled times averaging 18 hours in a six-day week enable me to visit the library up to three times in a day for one-hour periods each. Accessibility to library services is limited by my work program hours.

When scheduled, inmates line up in the hallway in front of the library entrance ( 1 in the diagram) where a librarian will go down the line asking if anyone wants to sign up for a music CD player or a video player. In this way inmates do not have to line up a second time to request this equipment, and congestion in the library itself is diminished.

Inmates then file into the library to sign in at the attendance $\log$ (2) after which I usually claim a seat in the reading area (3). Those who have signed up for $\mathrm{CD}$ or video players will go to check out the specific items they want (4). These might include newspapers up to seven days old, current monthly magazines, current daily newspapers from one of the ten largest cities in Wisconsin, and reference books, which may also be checked out for use in the library. I might check to see if I have any interlibrary loan books awaiting me. Others receive their assigned computer disc and proceed to the electronics room (5) where there are two electric typewriters, eight computer word processors, four video players, and three music $C D$ players available for inmates' use.

After checking with I.L.L., I move along to B.I.P. (Books in Print) (6) and select two books (weekly limit) to request on interlibrary loan. My subject areas are Christian Antiquity (BC $200-200 \mathrm{AD}$ ), Aquaculture, Origami, and any work that I may have heard about that is not at hand in the library. The library's computer catalogue (7) enables me to do a quick search by subject, author, and title to find whatever is new in the library, or I can just browse through the general library (8). The sci-fi and fantasy sections are favorites of mine.

The CD-ROM computers (9) have many educational programs of which I have used the spelling, math, astronomy, and foreign language programs. The library TV $(10)$ shows a video that can be viewed from a seat in the reading area.

Ten minutes before the period ends, an announcement is made calling for all materials to be returned and a last call is given for books to be checked out (11). The computerized bar-code system makes this process quick and easy.

\section{The Law Library}

The scheduling of law library hours coincides with the general library schedule except that the law library period is a two-hour block of time, up to two times in a day. This allows more time for an inmate to do legal research.

Entrance into the law library follows the same procedure as in the general library. Inmates line up outside the entrance (1) and when the period begins, sign in and claim a seat (3). An inmate can then utilize the resources of this library as his needs require (4). There is an inmate clerk available to help and assist in locating materials. The reference section (REF) has material ranging from blank forms commonly used in criminal and family law cases to books by judges on how to argue a case before the U.S. Supreme Court.

There are 12 distinct sections to the law library with each representing a level of hierarchy in the structure of the government. These are:

1. The Wisconsin Statues (STATS) - the statutory laws of the state of Wisconsin

2. The Wisconsin Key Digest

3. The Wisconsin Statues Annotated (KEY) bibliographical volumes that correlate court decisions rendered in relation to specific statutory passages and by subject areas

4. The Northwestern Reporter, 2nd edition (NW2) - the complete court decisions of the state court of appeals and supreme court cases dating back to 1963

5. The Federal Supplement (F.SUPP) - the complete court decisions of the federal district courts dating back to 1956

6. The Federal Reporter, $2^{\text {nd }}$ ed (F.2d) - federal court of appeals decisions dating from 1964 to 1993

7. The Federal Reporter, $3^{\text {rd }}$ ed. (F.3d) - federal court of appeals cases from 1993 to the present

8. The Supreme Court Reports (S.CT.) - the U.S. Supreme Court decisions dating back to 1956

9. Sheppard's (SHEP) - a bibliography that cross-references where one court decision was used in another court decision from state court to U.S. Supreme Court dating to 1794. 
10. The Federal Practice Digest (F.P.D.) - a symposium of Federal and U.S. Supreme Court decisions in relation to subject areas

11. The Corpus Juris Secundum (C.J.S.) - a symposium of the "law of the land", common to all the States of the Union arranged by subject area

12. The United States Code Annotated (U.S.C.A.) - the current statutory laws as passed by the U.S. Congress, stemming from the U.S. Constitution with cross-references to court decisions.

I have found that one of the hidden amusements of the law library is its historical accounts of human situations. Although the law library is primarily for use in helping to address legal issues, as recreational reading it can be amusing as well as educational.

\section{Satellite Services}

In addition to these main library services, there are eleven unit libraries, one for each inmatc-housing unit, having an average of 300 books each. The unit libraries are rotated among the housing units and updated and maintained from the main library. There is also an abridged law library for use by the inmate population in segregation.

In the visiting room there is a children's library. This satellite library is part of a reading program that enables inmates to read with and to their children during visits.

The prison library at Oshkosh Correctional Institution provides recreational and educational opportunities that are limited only with respect to prison security. The supportive atmosphere and willingness of the librarians to assist, encourages inmates who have incentive, to benefit from the services offered and to become enthused with something more than the mere thought that you are here, in a correctional institution.

Randy Purifoy is an inmate at Oshkosh Correctional Institution, Oshkosh, Wisconsin. He wishes to share with readers a sense of what it is like to use this prison library.

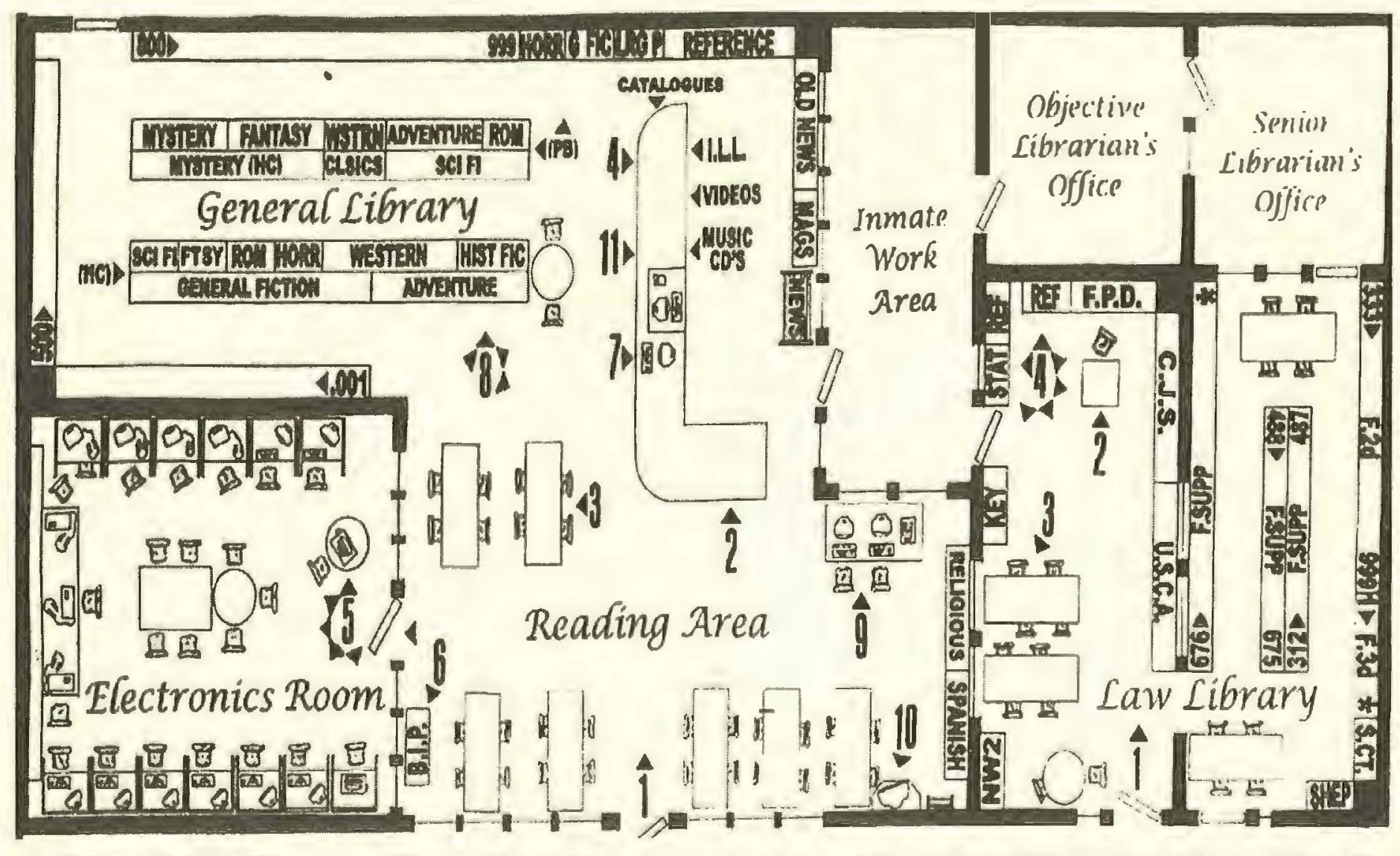

